\title{
Effects of Waste Water Irrigation on Physical and Biochemical Characteristics of Soil and Metal Partitioning in Beta vulgaris L.
}

\author{
Anita Singh • Madhoolika Agrawal
}

Received: 15 May 2012/ Accepted: 1 November 2012/Published online: 25 November 2012

(C) NAAS (National Academy of Agricultural Sciences) 2012

\begin{abstract}
The present study deals with the assessment of changes in physical and biochemical characteristics of soil and metal partitioning in Beta vulgaris L. grown in farmer's fields irrigated with waste water in Dinapur and Lohta areas of Varanasi, India, during December to February, 2007-2008 and 2008-2009. Nutrient concentrations, organic carbon, microbial biomass, $\mathrm{C}, \mathrm{N}$, and $\mathrm{P}$, enzymatic activities and heavy metal concentrations in soil and plant parts were estimated at waste water $\left(\mathrm{DW}_{1}, \mathrm{DW}_{2}\right.$ and $\left.\mathrm{LW}\right)$ and clean water-irrigated sites (DC and LC). Sites receiving waste water irrigation showed an increase in organic $\mathrm{C}$ by 36 and $64 \%$ and in available phosphorus by 15 and, $21 \%$ at $\mathrm{DW}_{1}$ and $\mathrm{DW}_{2}$ sites compared to DC and 88 and $29 \%$ at LW compared to LC during the first year. Dehydrogenase and urease activities increased two to threefold at waste water-irrigated sites compared to the respective clean water-irrigated ones during both the years of study. Microbial biomass $(\mathrm{C}, \mathrm{N}$, and $\mathrm{P})$ and concentrations of exchangeable cations $\left(\mathrm{Na}^{+}, \mathrm{K}^{+}\right.$, and $\mathrm{Ca}^{+2}$ ) also showed increments varying from two to threefold at waste water-irrigated sites. During both the years, total heavy metal concentration in soil was the highest for $\mathrm{Mn}$ followed by $\mathrm{Zn}, \mathrm{Pb}, \mathrm{Ni}, \mathrm{Cu}, \mathrm{Cr}$, and $\mathrm{Cd}$ at Dinapur, whereas at Lohta the trend was $\mathrm{Mn}, \mathrm{Zn}, \mathrm{Cr}, \mathrm{Pb}, \mathrm{Cu}$, and $\mathrm{Cd}$. The accumulation of heavy metals in the plants was several-fold higher in roots and shoots at waste water-irrigated sites, and $\mathrm{Cd}, \mathrm{Pb}$, and $\mathrm{Ni}$ were above the safe limits in edible tissues. Lower metal concentrations were recorded at $\mathrm{DW}_{1}$ site compared to $\mathrm{DW}_{2}$ and $\mathrm{LW}$ sites. The study suggests that waste water irrigation led to beneficial changes in physico-chemical and biological properties of the soil, but increased the soil contamination of heavy metals. However, the intermittent use of clean water in such areas may not only reduce the metal contamination in the plants but will also maintain soil fertility.
\end{abstract}

Keywords Heavy metal $\cdot$ Microbial biomass $\cdot$ Nutrient concentration $\cdot$ Waste water

\section{Introduction}

Population growth, especially in the developing countries, has increased the demand for a huge quantity of water for domestic, municipal, and industrial sectors. With the increasing scarcity of freshwater resources that are available to agriculture, the use of urban waste water for irrigation is increasing, especially in the arid and semi-arid regions of the world. The use of untreated waste water is

\footnotetext{
A. Singh $\cdot$ M. Agrawal $(\bowtie)$

Ecology Research Laboratory, Department of Botany,

Banaras Hindu University, Varanasi 221005, India

e-mail: madhoo.agrawal@gmail.com
}

particularly intense in areas where there is poor access to other sources of irrigation water [20]. The use of waste water for irrigating agricultural soil has been shown to be associated with a number of potential beneficial changes such as an increase in organic carbon, available nitrogen, phosphorus, potassium, and magnesium contents in soil as compared to the clean ground water-irrigated soil [36]. Waste water is a valuable source of plant nutrients and organic matter needed for maintaining fertility and productivity levels of the soil [39]. Irrigation with waste water has been shown to result in increase in growth, yield, and plant constituents [2].

Waste water contains significant amounts of organic and inorganic nutrients. There is a potential for the nutrients 
present in recycled water to be used as a fertilizer source when the water is recycled for irrigation. Soil microorganisms show increased metabolic activities under sewage effluent irrigation [28, 37]. Organic carbon, total nitrogen, microbial biomass $\mathrm{C}$ and $\mathrm{N}$ and microbial activities increased with increase in the time duration of waste water irrigation [37]. Concentrations of total $\mathrm{Mg}, \mathrm{Hg}, \mathrm{Mo}, \mathrm{Ca}$, $\mathrm{Cu}$, and $\mathrm{Cr}$, and available concentrations of $\mathrm{Pb}, \mathrm{Cd}$, and $\mathrm{Cu}$ increase significantly in soils under waste water irrigation, and the concentrations remain below the hazardous levels [37].

Soil enzyme activity was used to test the biochemical status of the soil system in Brazilian Oxisol irrigated with treated sewage effluent [16]. Results showed rapid mineralization of dissolved organic matter and rapid nitrification from ammonia and organic nitrogen due to treated sewage effluent [16]. Soil water-soluble organic carbon, soil microbial biomass, and $\beta$-glucosidase and alkaline phosphatase activities increased under treated waste water irrigation in the Mediterranean island of Mallorca, Spain [1]. Liu and Haynes [24] have shown that microbial community increased under waste water irrigation.

In contrast, some harmful effects like inhibition of root and shoot growth, and reduction in yield due to the accumulations of heavy metals in plants grown at waste waterirrigated fields are also reported [43].

Heavy metal accumulation is one of the major drawbacks in using waste water for irrigation [44]. Therefore, the present study was undertaken to evaluate the effect of waste water irrigation on physical and biochemical characteristics of soil and heavy metal buildup in soil and plants under natural field conditions with different intensities (wholly/intermittently) of waste water use. It was hypothesized that intermittent use of clean water between waste water irrigation will not only reduce the heavy metal load but also enhance the soil microbial activities to increase the fertility of soil. The pollution index was calculated to show the level of contamination in soil at differently waste water-irrigated sites.

\section{Materials and Methods}

\section{Study Area}

The study was conducted at Dinapur and Lohta areas of Varanasi $\left(25^{\circ} 18^{\prime} \mathrm{N}\right.$ latitude and $83^{\circ} 01^{\prime} \mathrm{E}$ longitude and $76.19 \mathrm{~m}$ a.s.1.) situated in the eastern Gangetic plain of India having long practices of waste water irrigation (about 20 years). At Dinapur, the main source of waste water is a sewage treatment plant (DSTP) of 80 million liters per day (MLD) capacity installed in 1986. DSTP not only receives sewage but also effluents discharged from various industries such as fabric printing, batteries, and paint in the urban areas of Varanasi. The treated waste water from the main outlet is directly used by farmers for irrigation. At Lohta area, sewage and industrial effluents from more than a hundred local industries located upstream of the drain at Chandpur, Maruadih, Lahartara, and Lohta industrial estates and from treatment plant of a large diesel locomotive works, manufacturing diesel engines are discharged and directly used by farmers for irrigating the agricultural fields.

The soil of the study sites is classified as Inceptisol, and is pale brown in color and sandy loam in texture (58\% sand, $15 \%$ silt, and $27 \%$ clay).

Based upon the type of irrigation practices, three subsites were selected at Dinapur $\left(\mathrm{DW}_{1}, \mathrm{DW}_{2}\right.$, and $\left.\mathrm{DC}\right)$ area. The $\mathrm{DW}_{1}$ site receives both clean (from bore well) as well as treated sewage water for irrigation, whereas the $\mathrm{DW}_{2}$ site receives only treated waste water. At the DC site, only clean water from bore wells is used for irrigation. At Lohta area, two sites were selected (LW and LC). The LW site is irrigated by untreated and treated waste water, while LC site is irrigated by clean water from a bore well.

\section{Field Preparation and Raising of Plants}

Farmer's fields following different irrigation regimes in Dinapur and Lohta were marked and a whole plot of $6.5 \times 4.5 \mathrm{~m}^{2}$ was prepared at each site $\left(\mathrm{DW}_{1}, \mathrm{DW}_{2}, \mathrm{DC}\right.$, LW, and LC). The whole plot was then divided into six subplots of $1.5 \times 1.5 \mathrm{~m}^{2}$ having margins of $0.5 \mathrm{~m}$. Genetically uniform seeds of palak (B. vulgaris L. var. All Green H1) procured from the Indian Institute of Vegetable Research, Varanasi, were sown $2 \mathrm{~cm}$ deep in five rows in each subplot. The irrigation was done either with the waste water at $\mathrm{DW}_{1}, \mathrm{DW}_{2}$, and LW sites and clean water at $\mathrm{DC}$ and LC at regular interval following the common schedule. The experiment was conducted from December 2007 to February 2008 and then repeated in the same months of 2008-2009.

Clean and waste water used for irrigation at Dinapur and Lohta showed variations in selected physico-chemical properties. In waste water, the values for $\mathrm{pH}$, conductivity, total dissolved solid (TDS), and biological oxygen demand were $6.89,0.78 \mathrm{ds} \mathrm{m}^{-1}, 596 \mu \mathrm{g} \mathrm{ml}^{-1}, 65.55 \mu \mathrm{g} \mathrm{ml}^{-} 1$, respectively, at Dinapur and $7.15,0.91 \mathrm{ds} \mathrm{m}^{-1}$ $691.6 \mu \mathrm{g} \mathrm{ml}^{-1}, 320.32 \mu \mathrm{g} \mathrm{ml}^{-1}$, respectively, at Lohta site. Clean water did not show significant variations in different characteristics between Dinapur and Lohta, and the values for $\mathrm{pH}$, conductivity $\left(\mathrm{ds} \mathrm{m}^{-1}\right)$, and $\operatorname{TDS}\left(\mu \mathrm{g} \mathrm{ml}^{-1}\right)$ ranged from 7.90-8.00, 0.57-0.59, and 425-461.6, respectively. The concentrations of $\mathrm{NO}_{3}{ }^{-}-\mathrm{N}, \mathrm{NH}_{4}{ }^{+}-\mathrm{N}$, total $\mathrm{P}, \mathrm{N}, \mathrm{Na}^{+}$, $\mathrm{K}^{+}$, and $\mathrm{Ca}^{+2}\left(\mu \mathrm{g} \mathrm{ml}^{-1}\right)$, respectively, were $2.00,11.7,0.24$, 5.4, 262.5, 135.4, and 248.5, in clean water and 5.30, 15.7, 9.7, 61.8, 281.5, 193.7, and 303.0 in waste water at Dinapur 
and $2.57,10.36,0.30,6.20,291.25,245.4$, and 252.1 in clean water and 7.56, 17.0, 10.9, 75.4, 305.0, 273.7, and 363.5 in waste water at Lohta. The concentrations of $\mathrm{Cd}, \mathrm{Cu}, \mathrm{Pb}, \mathrm{Zn}$, $\mathrm{Mn}, \mathrm{Ni}$, and $\mathrm{Cr}$ were non-detectable in clean water at both the sites, whereas in waste water the concentrations of these metals $\left(\mu \mathrm{g} \mathrm{ml}^{-1}\right.$ ) were 0.04, 0.053, 0.043, 0.117, 0.077, 0.020, and 0.050 at Dinapur and 0.037, 0.043, 0.063, 0.093, $0.110,0.050$, and 0.147 at Lohta, respectively.

\section{Soil Sampling and Preparation}

Monoliths of $10 \times 10 \times 15 \mathrm{~cm}^{3}$ soil in triplicates were collected from different subplots separately at $\mathrm{DW}_{1}, \mathrm{DW}_{2}$, DC, LW, and LC sites. Fresh soil samples were used for estimation of microbial biomass and soil enzyme activities and the rest of the soil samples were air-dried at room temperature, crushed, and passed through a sieve of 2-mmmesh size. The sieved samples were kept for analyzing various characteristics of the soil.

\section{Plant Sampling}

Plant samples were collected carefully without any disturbance to the root system at the time of maturity. Samples were then washed with the help of running tap water after keeping them on a 2.5-mm-mesh sieve to remove the soil particles adhering to the roots. The samples were separated into root and shoot parts and oven-dried separately at $80{ }^{\circ} \mathrm{C}$ until a constant weight was achieved. Plant samples were then powdered separately and stored at ambient temperature for further analysis of heavy metals. Samples collected from different plots were treated as replicates.

\section{Soil Analysis}

Soil $\mathrm{pH}$ was measured in suspension of 1:5 (soil: water w/v) using a glass electrode standardized with $\mathrm{pH} 4,7$, and 9.2 buffer tablets attached to an ion analyzer (Model E.A 940, Orion, USA). The organic carbon content was determined by using modified Walkley and Black's rapid titration method [7]. Nitrate nitrogen $\left(\mathrm{NO}_{3}{ }^{-}-\mathrm{N}\right)$ and ammoniacal nitrogen $\left(\mathrm{NH}_{4}{ }^{+}-\mathrm{N}\right)$ were estimated by $\mathrm{NO}_{3}{ }^{-}$ $\mathrm{N}$ and $\mathrm{NH}_{4}{ }^{+}-\mathrm{N}$ electrodes, respectively, with the help of the ion analyzer (Model E.A 940, Orion, USA).

The total nitrogen content was determined by following the Gerhardt-Kjeldahl technique through the Gerhardt automatic analyzer (Model KB8S, Kjeldatherm, Germany). Available phosphorus $\left(\mathrm{NaHCO}_{3}\right.$ extractable) was determined by the method given by [6]. Exchangeable cations such as $\mathrm{Na}, \mathrm{K}$, and $\mathrm{Ca}$ were extracted using ammonium acetate solution through repeated leaching technique [19] and contents were determined by atomic absorption spectrophotometer (Model 2380, Perkin Elmer, Inc., Norwalk, CT, USA).

Digestion and Analysis for Heavy Metals in Soil and Plant Parts

The oven-dried and sieved samples of soil and plant parts (1 g), were digested by adding tri-acid mixture $\left(\mathrm{HNO}_{3}\right.$, $\mathrm{H}_{2} \mathrm{SO}_{4}$, and $\mathrm{HClO}_{4}$ in a $5: 1: 1$ ratio) at $80{ }^{\circ} \mathrm{C}$ until a transparent solution was obtained [6]. After cooling, the digested sample was filtered using Whatman no. 42 filter paper and the filtrate was finally maintained to $50 \mathrm{ml}$ with distilled water. Concentrations of heavy metals in the filtrate of digested soil and plant samples were estimated by using atomic absorption spectrophotometer (Model 2380, Perkin Elmer, Inc., Norwalk, CT, USA) fitted with a specific lamp of particular metal using appropriate drift blank.

Phytoavailable heavy metals in the soil samples were extracted by the method given by Quevauviller et al. [34]. A sieved soil sample of $10 \mathrm{~g}$ was shaken with $20 \mathrm{ml}$ of $0.05 \mathrm{~N}$ EDTA solution ( $\mathrm{pH} \mathrm{7)}$ for $1 \mathrm{~h}$ and then kept for $24 \mathrm{~h}$ before filtering. The concentrations of phytoavailable heavy metals in the filtrate were determined by using atomic absorption spectrophotometer (Model 2380, Perkin Elmer, Inc., Norwalk, CT, USA).

\section{Pollution Index}

The pollution index (PI) was calculated by the following formula [36]:

$P I=C i / S i$

$\mathrm{Ci}$ : Heavy metal content in a soil sample $\left(\mathrm{mg} \mathrm{kg}^{-1}\right) ; \mathrm{Si}$ : Permitted standard of the same metal $\left(\mathrm{mg} \mathrm{kg}^{-1}\right)$.

When the $P I$ values exceed 1.0, then soil is said to be contaminated by anthropogenic inputs and requires continuous environmental monitoring of the area.

\section{Quality Control Analysis}

Precision and accuracy of heavy metal analysis was assured through repeated analysis of samples against the National Institute of Standard and Technology, Standard Reference Material (SRM 1570) for all the heavy metals. The results were found within $\pm 2 \%$ of the certified value. Quality control measures were taken to assess contamination and reliability of data. Blank and drift standards (Sisco Research Laboratories Pvt. Ltd., India) were run after five determinations to calibrate the instrument. The coefficients of variation of replicate analysis were determined for different determinations for precision of analysis and variations were found to be less than $10 \%$. 


\section{Enzymatic Activities}

Dehydrogenase activity in the soil was measured by the method given by Tabatabai [46]. A soil sample of $5 \mathrm{~g}$ was taken into a culture tube and $2.5 \mathrm{ml}$ of $1 \%$ sterile triphenyltetrazolium chloride solution and $2.5 \mathrm{ml}$ of $1 \%$ sterile glucose were added. The mixture was incubated for $48 \mathrm{~h}$ at $28^{\circ} \mathrm{C}$. After incubation, $25 \mathrm{ml}$ of methanol was added and the mixture was again incubated for $9 \mathrm{~h}$ at $28{ }^{\circ} \mathrm{C}$. Its activity was determined by taking the absorbance of triphenyl formazan (TPF) at $485 \mathrm{~nm}$ using a UVVIS spectrophotometer (Model 119, Systronics, India). Activity was calculated by the following formula.

Dehydrogenase activity $\left(\mu \mathrm{g}\right.$ TPF $\left.\mathrm{g}^{-1} \mathrm{hr}^{-1}\right)=\frac{O . D \times V}{W \times t}$

where $V=$ volume of the extract, $W=$ weight of soil, $t=$ incubation time.

Urease activity in the soil sample was estimated by following the method of Tabatabai [46]. A soil sample of $0.2 \mathrm{~g}$ taken in a culture tube was mixed with $0.1 \mathrm{ml}$ of toluene and $2 \mathrm{ml}$ of Tris buffer ( $\mathrm{pH} \mathrm{9)}$. Then, $0.5 \mathrm{ml}$ of urea solution was added and the mixture was incubated at $37{ }^{\circ} \mathrm{C}$ for $90 \mathrm{~min}$. After incubation, $0.2 \mathrm{ml}$ of $5 \mathrm{~N} \mathrm{NaOH}$ solutions along with distilled water was added to dilute the sample to $10 \mathrm{ml}$. Activity of urease enzyme was measured by estimating the concentration of ammonium produced using an ammonium selective electrode connected to an ion analyzer (Model EA 940, Orion, USA).

Urease activity $\left(\mathrm{mmol} \mathrm{NH}_{3} \mathrm{~g}^{-1} \mathrm{~h}^{-1}\right)$
$=\frac{\text { Concentration of ammonium ion }}{W \times t}$

$W=$ weight of soil, $t=$ incubation time.

\section{Microbial Biomass}

Soil microbial biomass (C, N, and P) was analyzed on the field moist soil. The samples were stored for 7 to 10 days at room temperature $\left(25-28^{\circ} \mathrm{C}\right)$ to settle down respiration. Microbial biomass $\mathrm{C}$ was determined using the $\mathrm{CHCl}_{3}$ fumigation extraction method of Vance et al. [47]. Biomass $\mathrm{N}$ and $\mathrm{P}$ was determined on the same field moist soil sample by following $\mathrm{CHCl}_{3}$ fumigation extraction methods proposed by Brookes et al. [8] and Brookes et al. [9], respectively.

\section{Statistical Analysis}

The data of heavy metal concentrations in the soil and in plant parts at different sites were subjected to ANOVA followed by Duncan's test for assessing the significance of differences. All the statistical tests were performed using SPSS software (SPSS Inc., version 12).

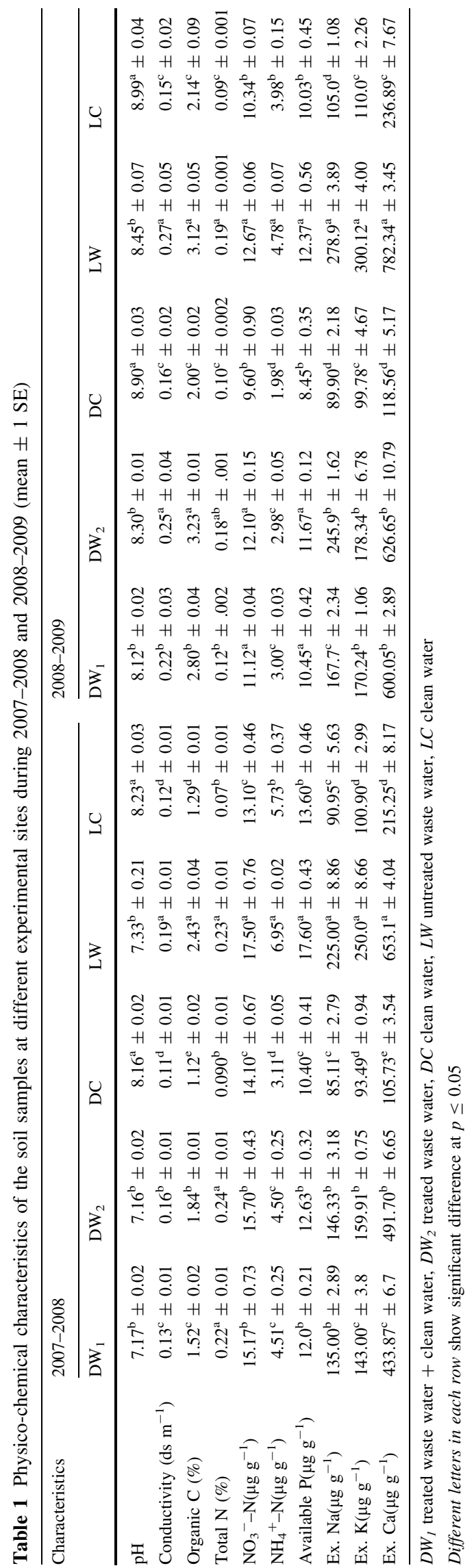




\section{Results}

Physico-chemical Characteristics of Soil

During the first year (2007-2008), soil from clean waterirrigated sites, i.e., DC and LC, showed significantly ( $p \leq 0.05$ ) higher $\mathrm{pH}$ values as compared to the waste water-irrigated sites, i.e., $\mathrm{DW}_{1}, \mathrm{DW}_{2}$, and LW (Table 1). Conductivity $\left(\mathrm{ds} \mathrm{m}^{-1}\right)$ of soil ranged from 0.136 to 0.196 at waste water-irrigated sites and $0.113-0.123$ at clean water-irrigated sites (Table 1). During the second year (2008-2009), clean water-irrigated sites also showed significantly higher $\mathrm{pH}(p \leq 0.05)$ and significantly lower conductivity ( $p \leq 0.05$ ) compared to the waste water-irrigated sites at Dinapur as well as Lohta sites (Table 1).

Organic $\mathrm{C}(p \leq 0.05)$ total $\mathrm{N}(p \leq 0.05)$ and available $\mathrm{P}$ $(p \leq 0.05)$ contents were significantly higher at waste water-irrigated sites $\left(\mathrm{DW}_{1}, \mathrm{DW}_{2}\right.$, and LW sites) as compared to the clean water-irrigated sites (DC and LC) during both years. Organic C content (\%) in the soil was 1.52, $1.84,1.12,2.43$, and 1.29 at the $\mathrm{DW}_{1}, \mathrm{DW}_{2}, \mathrm{DC}, \mathrm{LW}$, and LC sites, respectively, during the first year of sampling (Table 1). Total $\mathrm{N}$ and available $\mathrm{P}$ content were also higher in waste water $\left(\mathrm{DW}_{1}, \mathrm{DW}_{2}\right.$, and $\mathrm{LW}$ sites) irrigated sites as compared to respective clean water-irrigated sites (DC, LC). During the second year also, total N, organic C, and available $\mathrm{P}$ increased significantly $(p \leq 0.05)$ by 20,40 , and $24 \%$ at $\mathrm{DW}_{1}, 80,62$, and $38 \%$ at $\mathrm{DW}_{2}$ and 111,45 , and $23 \%$ at LW sites, respectively, as compared to their respective clean water-irrigated sites (Table 1).

During both of the years, $\mathrm{NO}_{3}{ }^{-}-\mathrm{N}$ and $\mathrm{NH}_{4}{ }^{+}-\mathrm{N}$ concentrations were significantly $(p \leq 0.05)$ higher at $\mathrm{DW}_{1}$, $\mathrm{DW}_{2}$, and LW sites as compared to respective sites receiving clean water for irrigation (Table 1). $\mathrm{NO}_{3}{ }^{-}{ }^{-} \mathrm{N}$ concentrations increased by 16,26 , and $23 \%$ and $\mathrm{NH}_{4}{ }^{+}-\mathrm{N}$ increased by 52,51 , and $20 \%$ at $\mathrm{DW}_{1}, \mathrm{DW}_{2}$, and $\mathrm{LW}$ sites, respectively, as compared to the respective clean water-irrigated sites during 2008-2009 (Table 1).

\section{Soil Enzyme Activities}

Dehydrogenase and urease activities in the soil were significantly higher $(p \leq 0.05)$ at waste water-irrigated sites $\left(\mathrm{DW}_{1}, \mathrm{DW}_{2}\right.$, and LW) as compared to the clean waterirrigated sites (DC and LC) in each year (Table 2). During 2007-2008, the average value of dehydrogenase activity was $34.67,39.00,22.67,37.87$, and $21.47 \mu \mathrm{M}$ TPF $\mathrm{g}^{-1} \mathrm{~h}^{-1}$ and urease was $2.37,3.09,1.21,2.83,1.14 \mathrm{~m} \mathrm{~mol}$ $\mathrm{NH}_{3} \mathrm{~g}^{-1} \mathrm{~h}^{-1}$ at $\mathrm{DW}_{1}, \mathrm{DW}_{2}, \mathrm{DC}, \mathrm{LW}$, and LC sites, respectively (Table 2). The trends of variations in enzyme activities between clean and waste water-irrigated sites were also similar for 2008-2009 (Table 2).

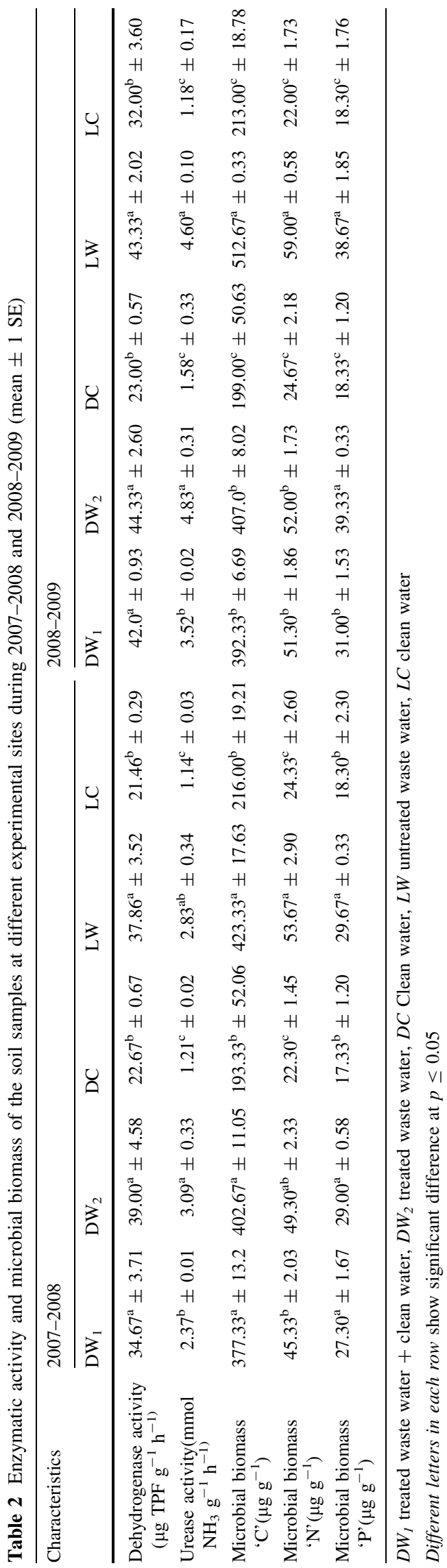


Microbial Biomass $\mathrm{C}, \mathrm{N}$, and $\mathrm{P}$

Microbial biomass $\mathrm{C}, \mathrm{N}$, and $\mathrm{P}$ was significantly higher $(p \leq 0.05)$ for waste water-irrigated $\mathrm{DW}_{1}, \mathrm{DW}_{2}$, and $\mathrm{LW}$ sites as compared to respective clean water-irrigated DC and LC sites (Table 2). Microbial biomass C in soil samples during 2007-2008 was 377.33, 402.67, 423.30, 193.33, and $216.00 \mu \mathrm{g} \mathrm{g}^{-1}$ at $\mathrm{DW}_{1}, \mathrm{DW}_{2}, \mathrm{LW}, \mathrm{DC}$, and LC sites, respectively. The values of microbial biomass $\mathrm{N}$ were significantly $(p \leq 0.05)$ higher than the values of microbial biomass $\mathrm{P}$ at all the sites (Table 2). Values of microbial biomass $\mathrm{C}, \mathrm{N}$, and $\mathrm{P}$ were higher at waste waterirrigated sites during the second year compared to the first year of sampling (Table 2).

Exchangeable $\mathrm{Na}, \mathrm{K}, \mathrm{Ca}$, and Heavy Metal Concentrations

During 2007-2008, exchangeable Na and K concentrations $\left(\mu \mathrm{g} \mathrm{g}^{-1}\right)$ were about twofold higher and of $\mathrm{Ca}$ about fourfold higher at all the waste water-irrigated sites as compared to the clean water-irrigated sites (Table 1). During 2008-2009, increments in concentrations were about $24,68,6,24$, and $15 \%$ for $\mathrm{Na}, 19,12,7,20$, and $9 \%$ for $\mathrm{K}, 55,33,12,20$, and $10 \%$ for $\mathrm{Ca}$ at $\mathrm{DW}_{1}, \mathrm{DW}_{2}, \mathrm{DC}$, LW, and LC sites, respectively, as compared to respective cations recorded during 2007-2008 (Table 1).

At all the sites, phytoavailability of $\mathrm{Mn}$ in the soil was highest followed $\mathrm{Cu}, \mathrm{Pb}, \mathrm{Cr}, \mathrm{Cd}, \mathrm{Zn}$, and Ni. Waste waterirrigated sites showed significantly higher $(p \leq 0.05)$ values of phytoavailable heavy metals as compared to the clean water-irrigated sites during both years of sampling (Table 3).

During both the years, total heavy metal concentration in the soil was the highest for Mn followed by $\mathrm{Zn}, \mathrm{Pb}, \mathrm{Ni}$, $\mathrm{Cu}, \mathrm{Cr}$, and $\mathrm{Cd}$ at Dinapur, whereas at Lohta it was the highest for $\mathrm{Mn}$ followed by $\mathrm{Zn}, \mathrm{Cr}, \mathrm{Pb}, \mathrm{Cu}, \mathrm{Ni}$, and $\mathrm{Cd}$ (Fig. 1a, b). Samples collected during the second year showed that among all the heavy metals, $\mathrm{Pb}, \mathrm{Mn}, \mathrm{Ni}$, and $\mathrm{Cr}$ concentrations were the highest at the LW site as compared to the waste water-irrigated sites of Dinapur. Among all the waste water-irrigated sites, $\mathrm{DW}_{1}$ site showed lower concentrations of all the metals compared to $\mathrm{DW}_{2}$ and LW sites (Fig. 1a, b). The pollution index value was less than 1 for all the metals except for $\mathrm{Cd}$ at waste water-irrigated site LW during 2007-2008 (Table 4).

Heavy Metal Concentrations in Root and Shoot Parts of Plant

Heavy metal concentrations in root and shoot portions were significantly higher $(p \leq 0.05)$ at waste water-irrigated sites as compared to clean water-irrigated ones in both

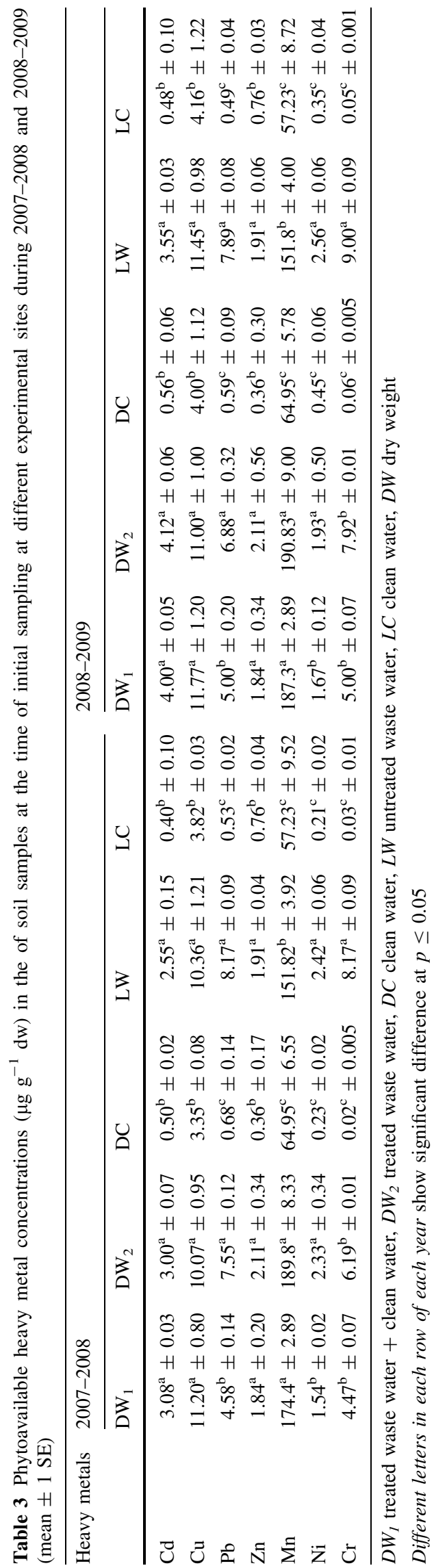


Fig. 1 a Concentrations of $\mathrm{Cd}$, $\mathrm{Cu}, \mathrm{Pb}$, and $\mathrm{Zn}\left(\mu \mathrm{g} \mathrm{g}^{-1} \mathrm{dw}\right)$ of the soil samples at different experimental sites during 2007-2008 and 2008-2009.

Values are mean \pm 1 SE. Bars with different letters in each group show significant difference at $p<0.05$. b Concentrations of $\mathrm{Mn}, \mathrm{Ni}$, and $\mathrm{Cr}\left(\mu \mathrm{g} \mathrm{g}{ }^{-1} \mathrm{dw}\right)$ of the soil samples at different experimental sites during 2007-2008 and 2008-2009. Values are mean \pm 1 SE. Bars with different letters in each group show significant difference at $p<0.05$

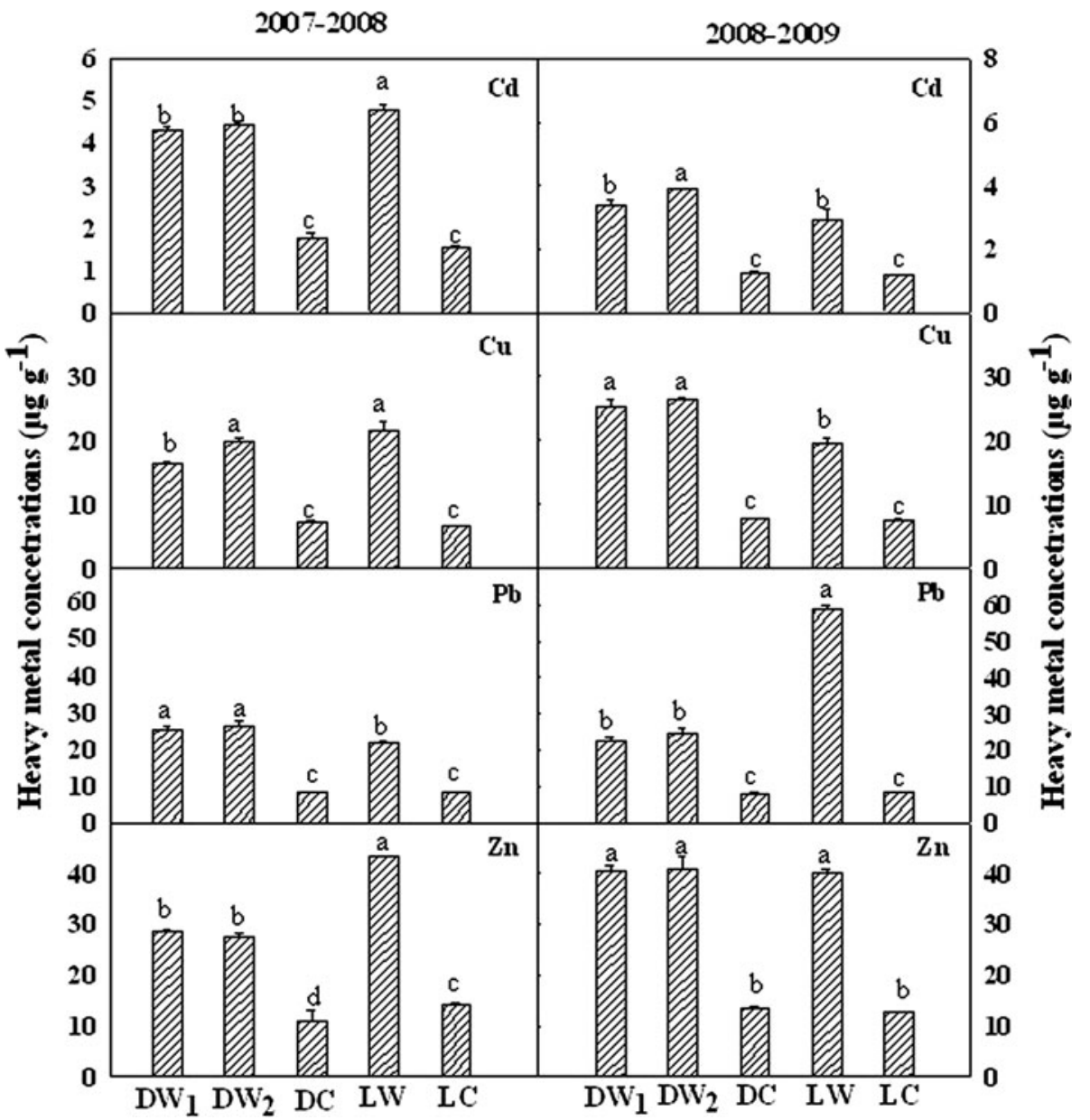

years, but were higher in 2008-2009 compared to 2007-2008 (Figs. 2, 3). At both the samplings, heavy metal concentrations were higher in shoot compared to the root portion during both the samplings (Figs. 2, 3). Among all the heavy metals, $\mathrm{Zn}$ concentration was the highest and $\mathrm{Cd}$ concentration was the lowest in root part at all the sites. In shoot portion, Mn concentration was the highest and $\mathrm{Cd}$ was the lowest (Figs. 2, 3). During 2008-2009 at $\mathrm{DW}_{1}$, $\mathrm{DW}_{2}, \mathrm{DC}, \mathrm{LW}$, and LC sites, Cd concentrations $\left(\mu \mathrm{g} \mathrm{g}^{-1}\right.$ $\mathrm{dw}$ ) in edible portion ranged from 4.75 to $6.16, \mathrm{Cu}$ from 20.28 to $25.10, \mathrm{~Pb}$ from 25.50 to $30.33, \mathrm{Zn}$ from 53.02 to 56.73, Ni from 21.32 to 33.28 , and $\mathrm{Cr}$ from 6.03 to 8.59 (Fig. 3). In the edible portion of palak (shoot), the concentrations of $\mathrm{Cd}, \mathrm{Pb}$, and $\mathrm{Ni}$ were higher than the Indian permissible limits (Awashthi 2000), and permissible value in food provided by FAO/WHO (Codex Alimentarius, 2007) at all the waste water-irrigated sites.

\section{Discussion}

The soil of both the sites irrigated by waste water in both years had significantly lower $\mathrm{pH}$ and higher conductivity than the soil of clean water-irrigated sites. A reduction in soil $\mathrm{pH}$ due to waste water irrigation compared to irrigation by potable water has been reported [29]. Higher concentrations of ammonium ions in waste water may lead to a higher rate of nitrification releasing free hydrogen ions in the soil, thus lowering the soil $\mathrm{pH}[18,48]$. Higher accumulation of total dissolved solids in the soil due to continuous use of waste water may enhance the conductivity of soil at waste water-irrigated sites. Mohammad and Mazahreh [29] have also recorded higher conductivity in waste water-irrigated than clean water-irrigated soil.

Similar to the present study, Onweremadu [32] also showed increments in organic matter, available $\mathrm{P}$ and total $\mathrm{N}$, at waste water-irrigated soil as compared to the clean water-irrigated soil of Imo State University, Owerri, Nigeria. Similarly, Masto et al. [27] have recorded 18.2 and $240.67 \%$ increments in total $\mathrm{N}$ and available $\mathrm{P}$, respectively, in the soil irrigated by sewage water from a sewage treatment plant at IARI farm, New Delhi. The range of organic C (1.52-2.43\%) recorded during the present study was higher than the range (1.68-1.78\%) reported by Yadav et al. [50] in soil irrigated by sewage water from urban estate of Kurukshetra, Haryana. Friedel et al. [13] 
Fig. 1 continued

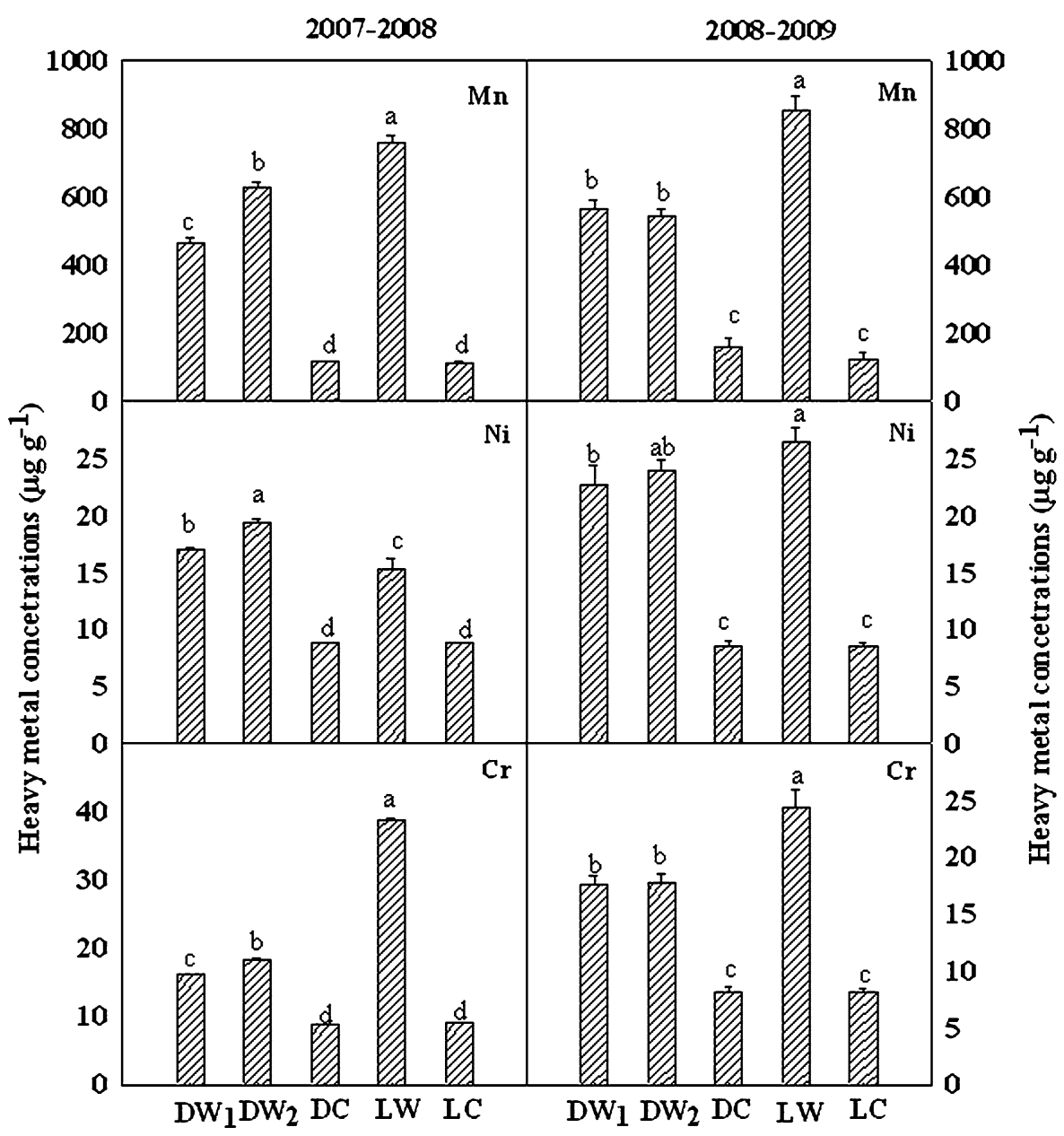

Table 4 Pollution index at different experimental sites during 2007-2008 and 2008-2009

\begin{tabular}{|c|c|c|c|c|c|c|}
\hline \multirow[t]{2}{*}{ Heavy metals } & \multicolumn{3}{|c|}{ 2007-2008 } & \multicolumn{3}{|c|}{ 2008-2009 } \\
\hline & $\mathrm{DW}_{1}$ & $\mathrm{DW}_{2}$ & LW & $\mathrm{DW}_{1}$ & $\mathrm{DW}_{2}$ & LW \\
\hline $\mathrm{Cd}$ & 0.95 & 0.98 & 1.06 & 0.74 & 0.86 & 0.65 \\
\hline $\mathrm{Cu}$ & 0.08 & 0.09 & 0.11 & 0.12 & 0.13 & 0.09 \\
\hline $\mathrm{Pb}$ & 0.10 & 0.10 & 0.08 & 0.18 & 0.19 & 0.46 \\
\hline $\mathrm{Zn}$ & 0.06 & 0.07 & 0.09 & 0.09 & 0.10 & 0.08 \\
\hline $\mathrm{Mn}$ & $\mathrm{n} / \mathrm{a}$ & $\mathrm{n} / \mathrm{a}$ & $\mathrm{n} / \mathrm{a}$ & $\mathrm{n} / \mathrm{a}$ & $\mathrm{n} / \mathrm{a}$ & $\mathrm{n} / \mathrm{a}$ \\
\hline $\mathrm{Ni}$ & 0.15 & 0.17 & 0.14 & 0.20 & 0.21 & 0.23 \\
\hline $\mathrm{Cr}$ & $\mathrm{n} / \mathrm{a}$ & $\mathrm{n} / \mathrm{a}$ & $\mathrm{n} / \mathrm{a}$ & $\mathrm{n} / \mathrm{a}$ & $\mathrm{n} / \mathrm{a}$ & $\mathrm{n} / \mathrm{a}$ \\
\hline
\end{tabular}

$D W_{l}$ treated waste water + clean water, $D W_{2}$ treated waste water, $D C$ clean water, $L W$ untreated waste water, $L C$ clean water, $n / a$ not available (permissible limits for $\mathrm{Mn}$ and $\mathrm{Cr}$ in soil are not available)

have also reported 2.5 -fold increments in organic carbon content of soil irrigated by untreated sewage effluents from Mexico City. The Lohta site, where untreated waste water was used for irrigation, showed higher concentrations of exchangeable cations compared to Dinapur, having the use of treated waste water for irrigation. Garg and Kaushik [15] have shown higher concentrations of exchangeable $\mathrm{Ca}$ and $\mathrm{K}$ in untreated textile mill waste water as compared to the treated ones. Waste water irrigation was found to act as a supplement to soil fertility by adding organic matter and mobile compounds of nutrients $[21,40]$. Soil irrigated with waste water showed increments in total phosphorus, nitrogen, sodium, potassium, and iron concentrations [30]. 
Fig. 2 Metal concentration $\left(\mu \mathrm{g} \mathrm{g}^{-1} \mathrm{dw}\right)$ in shoots and roots of plants grown at different experimental sites during 2007-2008. Curved line with different capital letters in each group show significant difference in shoot and curved line with different small letters show significant difference in root part of plant at $p \leq 0.05$
2007-2008

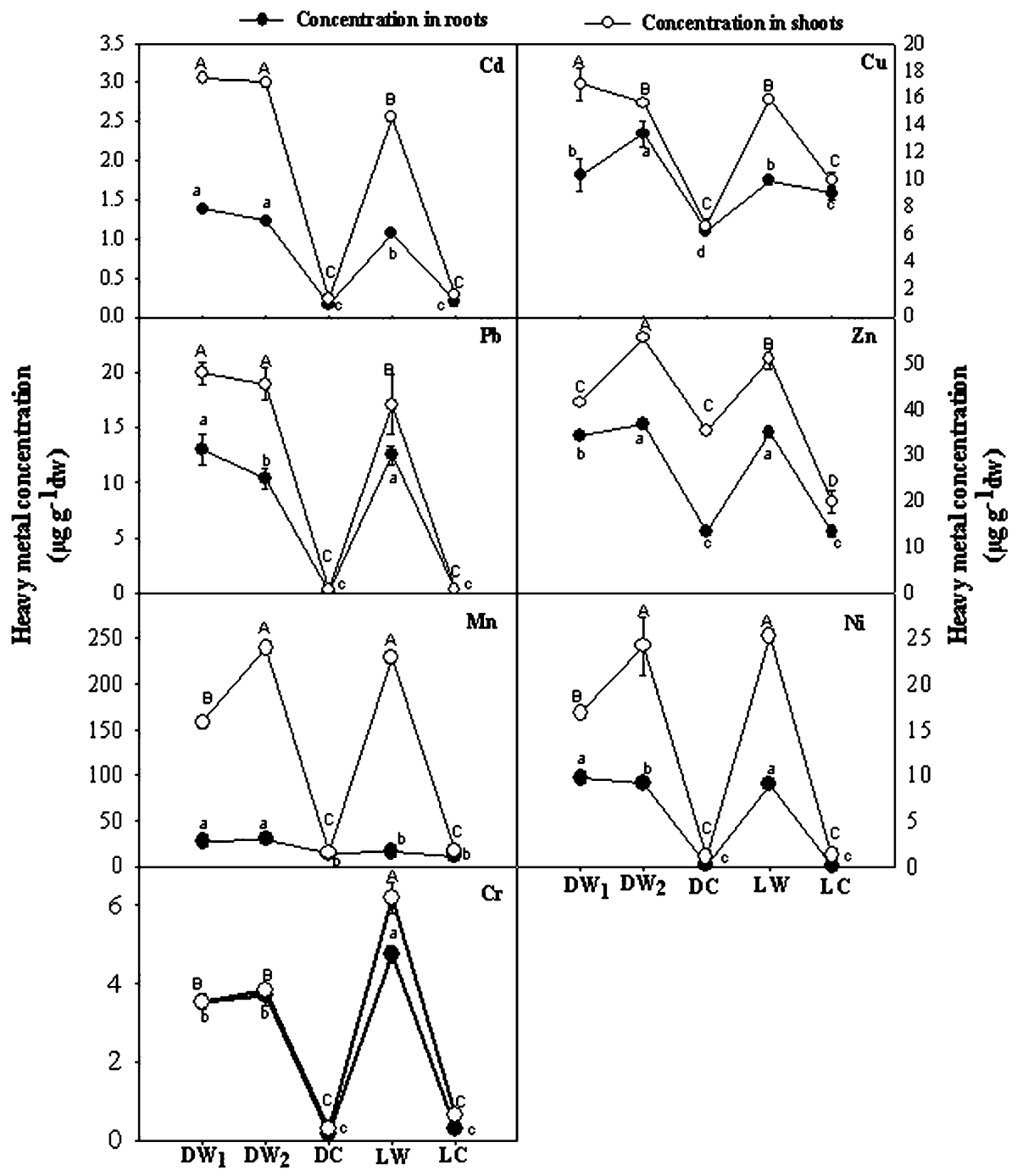

Microbial biomass is a more sensitive indicator of changing soil condition than the total organic matter. Microbial biomass $\mathrm{C}, \mathrm{N}$, and $\mathrm{P}$ were higher at waste waterirrigated compared to the clean water-irrigated sites. Soil irrigated by municipal waste water showed enhanced microbial activity and their biomass [24,37]. The study of the long-term effect of waste water irrigation on selected microbiological and biochemical characteristics of the soil showed that microbial biomass and activity of dehydrogenase enzyme in soil increased due to waste water irrigation [17]. Higher microbial activity and organic C content in treated waste water-irrigated field located in the central coastal region of Israel was also reported [12].

An increase in microbial activity due to waste water irrigation led to the increments in the activities of dehydrogenase and urease enzymes during the present study. Low (60-75 $\mathrm{mm}$ waste water per treatment) and high dose (120-150 mm waste water per treatment) of waste water treatments increased the dehydrogenase activity by 44 and
$27 \%$, respectively, in the soil from Lubin, Poland [10]. Dehydrogenase is an intracellular enzyme involved in microbial $\mathrm{O}_{2}$ metabolism. Activity of this enzyme depends upon the metabolic state of the soil biota and thus is a good indicator of soil microbial activity [14]. Urease enzyme is involved in the hydrolysis of $\mathrm{C}-\mathrm{N}$ bonds of amide and urea. Due to the higher amount of organic $\mathrm{N}$ incorporated in the soil through waste water irrigation, urease synthesis may have increased. Although the long-term use of waste water also led to an increase in heavy metal concentrations in the soil, the levels were not up to the extent that may have caused any negative effects on the measured enzymatic activities. Madejon et al. [25] have also reported that the addition of organic materials through municipal solid waste at doses of $50,000 \mathrm{~kg} \mathrm{ha}^{-1}$ did not negatively affect the dehydrogenase and urease activities of the soil even at higher availability of heavy metals. Chatzakis et al. [11] have shown that activities of dehydrogenase enzyme were enhanced by irrigating the soil with secondary treated 
Fig. 3 Metal concentration $\left(\mu \mathrm{g} \mathrm{g}^{-1} \mathrm{dw}\right)$ in shoots and roots of plants grown at different experimental sites during 2008-2009. Curved line with different capital letters in each group show significant difference in shoot and curved line with different small letters show significant difference in root part of plant at $\mathrm{p} \leq 0.05$
2008-2009

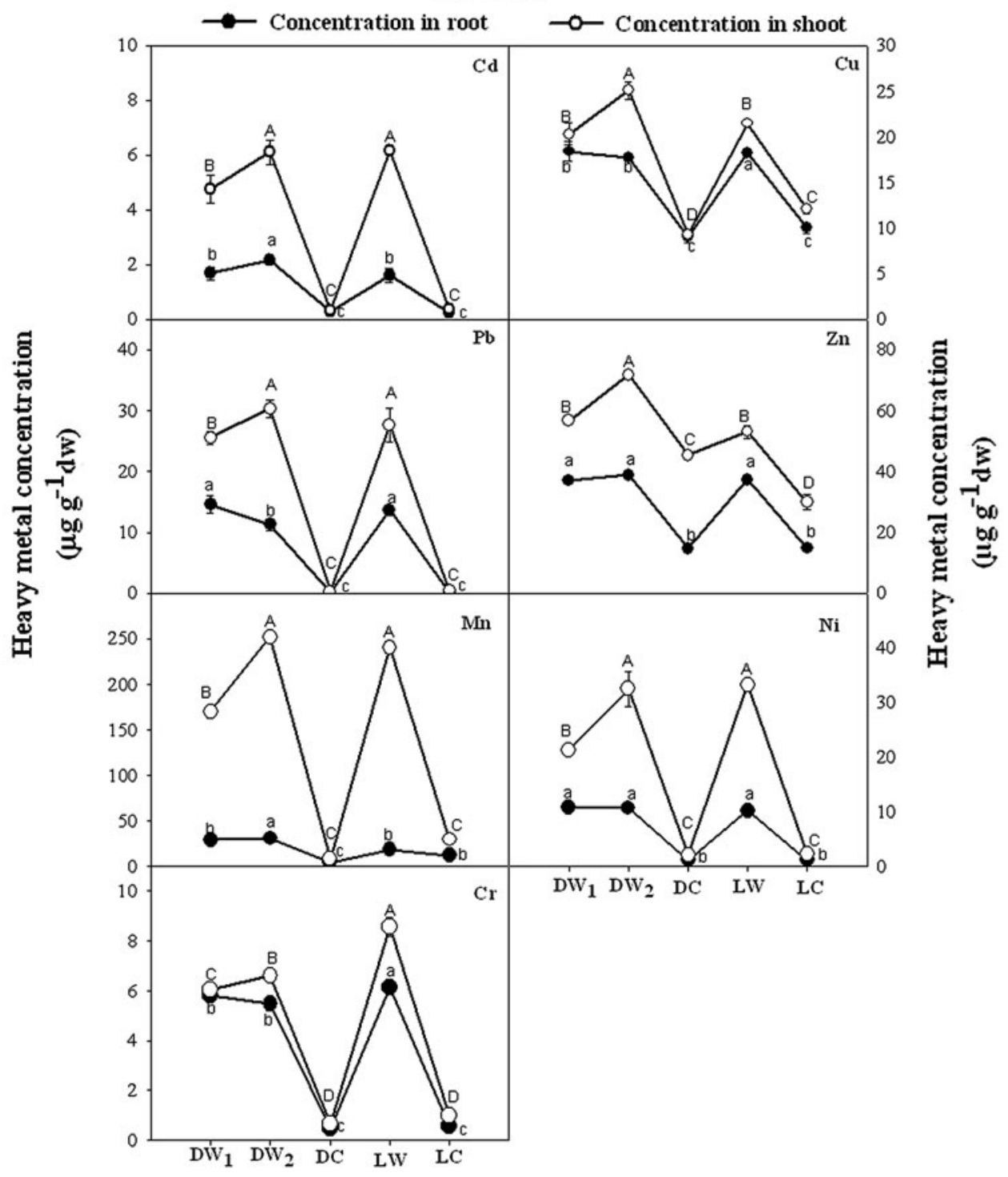

waste water effluent as compared to the fresh water irrigated one.

Low $\mathrm{pH}$ of waste water-irrigated soil increased the metal availability since the hydrogen ions have a greater affinity for competing with metal ions and releasing them from the soil solution for uptake. Total and phytoavailable heavy metal concentrations were significantly high in the soil at waste water-irrigated sites for all the metals as compared to the clean water-irrigated sites. Availability of heavy metals to plants depends upon solubility rate and various physicochemical properties of the soil, like $\mathrm{pH}$, organic carbon, cation exchange capacity, and soil texture [49]. The waste waters at both the sites had higher concentrations of heavy metals, while no heavy metals were detected in clean water.

In the present study, Mn concentration was $546.65 \mu \mathrm{g} \mathrm{g}^{-1}$ and Cd was $5.62 \mu \mathrm{g} \mathrm{g}^{-1}$ in the soil of Dinapur ( $\mathrm{DW}_{1}$ site). These values were higher than for the Mn $\left(156.96 \mu \mathrm{g} \mathrm{g}^{-1}\right)$ and $\mathrm{Cd}\left(2.80 \mu \mathrm{g} \mathrm{g}^{-1}\right)$ reported by Sharma et al. [41] during 2006-2007 at the same site, but more or less similar to the values reported by Singh et al. [43] during 2008-2009. Cu $\left(16.43 \mu \mathrm{g} \mathrm{g}^{-1}\right), \mathrm{Pb}\left(25.33 \mu \mathrm{g} \mathrm{g}^{-1}\right), \mathrm{Zn}\left(28.45 \mu \mathrm{g} \mathrm{g}^{-1}\right)$, and $\mathrm{Cr}\left(16.00 \mu \mathrm{g} \mathrm{g}^{-1}\right)$ concentrations at the $\mathrm{DW}_{1}$ site in the present study were lower than the reported for $\mathrm{Cu}$ (74.48 $\left.\mu \mathrm{g} \mathrm{g}^{-1}\right), \mathrm{Pb}\left(133.86 \mu \mathrm{g} \mathrm{g}^{-1}\right), \mathrm{Zn}\left(132.91 \mu \mathrm{g} \mathrm{g}^{-1}\right)$ and $\mathrm{Cr}\left(54.87 \mu \mathrm{g} \mathrm{g}^{-1}\right)$ by Singh et al. [43] at the same site. Lower concentrations of heavy metals $(\mathrm{Cd}, \mathrm{Cu}, \mathrm{Mn}, \mathrm{Ni}$, and $\mathrm{Cr}$ ) in the soil at $\mathrm{DW}_{1}$ site may be ascribed to the intermittent use of clean water for irrigation, which has caused lower accumulation of heavy metals in the soil compared to the $\mathrm{DW}_{2}$ site, where use of treated and untreated waste water for irrigation is a regular practice. The Lohta site contained the highest concentrations of most of the estimated heavy metals in the soil, due to the fact that many of the industries in this area are associated with significant heavy metal discharge 
and irrigation water is drawn directly from industrial effluents and waste water containing channels [3]. The waste water from Lohta had higher concentrations of heavy metals compared to Dinapur.

Pollution index calculation suggests that heavy metal concentrations in soil at waste water-irrigated sites $\mathrm{DW}_{1}$, $\mathrm{DW}_{2}$, and LW were mostly within the permissible limit, except for Cd during 2007-2008. The pollution index for $\mathrm{Cd}$ was the highest among all the heavy metal at all the sites. As agriculture is continuously practiced in the area throughout the year, soil buildup of heavy metals is minimized due to absorption by plants and leaching to lower horizons.

Heavy metal concentrations in root and shoot portions of palak plants were significantly higher at waste water-irrigated sites as compared to the clean water-irrigated ones. Similar to the present study, many-fold increments in the concentrations of $\mathrm{Zn}, \mathrm{Cu}, \mathrm{Mn}, \mathrm{Pb}, \mathrm{Cd}$, and $\mathrm{Ni}$ in roots and leaves of cauliflower, Indian spinach, and carrot plants grown under municipal sewage water irrigated soils were reported by Malla and Totawat [26]. Irrigation by effluent water from the Esfahan treatment plant increased the concentrations of $\mathrm{Fe}, \mathrm{Cu}$, and $\mathrm{Zn}$ in the roots of wheat and $\mathrm{Mn}$ and $\mathrm{Zn}$ in grains of wheat as compared to those irrigated with well water [35]. A field experiment was conducted to investigate the extent of translocation of heavy metals to tomato (Solanum lycopersicon L. cvs. "GS12" and "RS589956") fruit produced in an open field near Abu-Nusiar Waste Water Treatment Plant, Amman, Jordan. Tomato fruits showed elevated concentrations of $\mathrm{Fe}$, $\mathrm{Cu}, \mathrm{Ni}, \mathrm{Mn}$, and $\mathrm{Zn}$ under waste water irrigation [4, 5]. Kalavrouziotis et al. [22] have evaluated effects of municipal reclaimed waste water on the macro- and micro-element status of the soil and of Brassica oleracea var. Italica and Gemmifera. Use of treated municipal waste water for irrigation led to increases in the heavy metal load for both the varieties. Mojri and Amirossadt [31] have also observed high concentrations of $\mathrm{Cd}, \mathrm{Mn}$, and $\mathrm{Ni}$ in Zea mays grown in urban waste water-irrigated fields compared to clean water-irrigated ones.

Palak plants growing at all sites showed a higher accumulation of heavy metals in shoot than root. Sinha et al. [45] have also reported lower concentrations of heavy metals in the root as compared to the shoot in palak plants grown at sites near Gomti River, Lucknow. Heavy metals tend to remain in root tissue in most of the horticultural crops [23, 33], but palak did not show a similar trend. This may be ascribed to several-fold larger above-ground biomass of palak than the below-ground and also to high relative growth rate of this plant. Heavy metals like $\mathrm{Zn}, \mathrm{Cu}$, $\mathrm{Fe}, \mathrm{Mn}, \mathrm{Ni}$, etc., were reported to accumulate more in shoots of leafy vegetables, especially spinach as compared to the grain-yielding plants [38]. In between $\mathrm{DW}_{1}$ and $\mathrm{DW}_{2}$ sites, $\mathrm{DW}_{1}$ showed lower concentrations of the heavy metals in the edible portion of palak, which may be due to intermittent use of clean water for irrigation at the site. So our hypothesis that intermittent use of clean water with waste water will not only increase the yield but also maintain soil fertility has proven correct.

\section{Conclusions}

The results of both the years of study clearly showed that physico-chemical and biological properties of the soil were modified under long-term uses of waste water irrigation in Dinapur and Lohta areas. Soil $\mathrm{pH}$ decreased, whereas organic $\mathrm{C}$, total $\mathrm{N}$, available $\mathrm{P}$, and exchangeable cations increased under the waste water-irrigation regime. Heavy metal concentrations in the soil increased several fold at waste water-irrigated sites as compared to the clean waterirrigated ones. Higher values of microbial biomass $\mathrm{C}, \mathrm{N}$, and $\mathrm{P}$ and higher enzymatic activities at waste water-irrigated sites maintained higher soil fertility level compared to clean water-irrigated sites. Pollution index values showed that the concentrations of heavy metals in soil at waste water-irrigated sites were mostly not at the levels that cause metal pollution, but $\mathrm{Cd}$ has the potential to cause adverse effects in view of higher index. The present 2-year study conducted in natural field conditions having longterm practices of using waste water irrigation suggests that heavy metal contamination of the food chain with $\mathrm{Cd}, \mathrm{Pb}$, and $\mathrm{Ni}$ is a major issue in the area, having risks to human health. Among different irrigation patterns, the intermittent use of clean water with waste water reduced the metal concentrations in soil and plants. Therefore, this kind of irrigation pattern enhanced the potential for long-term use of waste water for irrigation by reducing the translocation of metals in plants from soil, which will maintain food safety and reduce the vulnerability to human health.

Acknowledgments Anita Singh is thankful to the Center for Advanced Study in Botany, Banaras Hindu University, Varanasi, for Senior Research Fellowship during the work.

\section{References}

1. Adrover M, Farrús E, Moyà G, Vadell J (2012) Chemical properties and biological activity in soils of Mallorca following twenty years of treated waste water irrigation. J Environ Manag 95:188-192

2. Aghtape AA, Ghanbari A, Sirousmehr A, Siahsar B, Asgharipour M, Tavssoli A (2011) Effect of irrigation with waste water and foliar fertilizer application on some forage characteristics of foxtail millet (Setaria italica). Int J Plant Physiol Biochem 3(3):34-42

3. Agrawal M (2004) Contaminated irrigation water and food safety for the peri-urban poor: appropriate measures for monitoring and 
control. Inception report submitted to Department of International Development, U.K, R 8160

4. Al-Lahham O, El Assi NM, Fayyad M (2003) Impact of treated waste water irrigation on quality attributes and contamination of tomato fruit. Agric Water Manag 61:51-62

5. Al-Lahham O, El Assi NM, Fayyad M (2007) Translocation of heavy metals to tomato (Solanum lycopersicon L.) fruit irrigated with treated waste water. Sci Hortic 113:250-254

6. Allen SE, Grimshaw HM, Rowland AP (1986) Chemical analysis. In: Moore PD, Chapman SB (eds) Methods in plant ecology. Blackwell Scientific Publication, Oxford, pp 285-344

7. Allison LE (1986) Organic carbon. In: Klute A (ed) Methods of soil analysis, part I. American Society of Agronomy, Madison, pp 1367-1381

8. Brookes PC, Powlson DS, Jenkinson DS (1982) Measurement of microbial biomass phosphorus in soil. Soil Biol Biochem 14:319-329

9. Brookes PC, Lundman A, Pruden G, Jenkinson DS (1985) Chloroform fumigation and release of nitrogen, a rapid direct method for measuring microbial biomass $\mathrm{N}$ in soil. Soil Biol Biochem 1:837-842

10. Brzezinska M, Stepniewska Z, Stepniewski W (2001) Dehydrogenase and catalase activity of soil irrigated with municipal waste water. Pol J Environ Stud 10(5):307-311

11. Chatzakis MK, Tzanakakis VA, Mara DD, Angelakis AN (2011) Irrigation of castor bean (Ricinus communis L.) and sunflower (Helianthus annus L.) plant species with municipal waste water effluent: impacts on soil properties and seed yield. Water 3:1112-1127

12. Elifantz H, Kautsky L, Mor-Yosef M, Tarchitzky J, Bar-Tal A, Chen Y, Minz D (2011) Microbial activity and organic matter dynamics during 4 years of irrigation with treated waste water. Microb Ecol 62:973-981

13. Friedel JK, Langer T, Siebe C, Stahr K (2000) Effects of longterm waste water irrigation on soil organic matter, soil microbial biomass and its activities in central Mexico. Biol Fert Soils $31: 414-421$

14. Garcia C, Hernandez T, Costa F, Ceccanti B (1994) Biochemical parameters in soils regenerated by the addition of organic wastes. Waste Manag Res 12:457-466

15. Garg VK, Kaushik P (2006) Influence of short-term irrigation of textile mill waste water on the growth of chickpea cultivars. Chem Ecol 22(3):193-200

16. Gloaguen TV, Forti MC, Lucas Y, Montes CR, Goncalves RAB, Herpin U, Melfi AJ (2007) Soil solution chemistry of a Brazilian Oxisol irrigated with treated sewage effluent. Agric Water Manag 88:119-131

17. Goyal S, Chander K, Kapoor K (1995) Effect of distillery waste water application on soil microbiological proper ties and plant growth. Environ Ecol 13(1):89

18. Hayes AR, Mancino CF, Pepper IL (1990) Irrigation of turf grass with secondary sewage effluent. I. Soil and leachate water quality. J Agron 82:939-943

19. Jackson ML (1958) Soil chemical analysis. Prentice-Hall of India, New Delhi, p 498

20. Jalali M, Merikhpour H, Kaledhonkar MJ, Seatm VDZ (2007) Nickel in a tropical soil treated with sewage sludge and cropped with maize in a long-term field study. Agric Water Manag 95:143-153

21. Jothimani P, Prabakaran J, Bhaskaran A (2002) Characterization and impact of dyeing factory effluent on germination and growth of maize and cowpea. Madras Agric J 89(10-12):568-571

22. Kalavrouziotis IK, Robolas P, Koukoulakis PH, Papadopoulos AH (2008) Effects of municipal reclaimed waste water on the macro- and micro-elements status of soil and of Brassica oleracea var. Italica, and B. oleracea var. Gemmifera Agric Water Manag 95:419-426

23. Kim SJ, Chang AC, Page AL, Warneck JE (1988) Relative concentration of cadmium and zinc in tissue of selected food plants grown on sewage sludge treated soils. J Environ Qual $17: 568-573$

24. Liu YY, Haynes RJ (2010) Long-term irrigation with dairy factory waste water influences soil quality. World Acad Sci Eng Technol 70:577-581

25. Madejon E, Burgos P, Lopez R, Cabrera F (2001) Soil enzymatic responses to addition of heavy metals with organic residues. Biol Fertil Soil 34:144-150

26. Malla R, Totawat KL (2006) Effect of municipal sewage on soil properties and chemical build-up in vegetable crops grown on Haplusteps of sub-humid southern plains of Rajasthan. J Indian Soci Soil Sci 54(2):226-231

27. Masto R, Chhonkar P, Singh D, Patra A (2009) Changes in soil quality indicators under long-term sewage irrigation in a subtropical environment. Environ Geol 56:1237-1243

28. Meli S, Porto M, Belligno A, Bufo SA, Mazzatura A, Scopa A (2002) Influence of irrigation with lagooned urban waste water on chemical and microbiological soil parameters in a citrus orchard under Mediterranean conditions. Sci Total Environ 285:69-77

29. Mohammad MJ, Mazahreh N (2003) Changes in soil fertility parameters in response to irrigation of forage crops with secondary treated waste water. Commun Soil Sci Plant Anal 34(9-10):1281-1294

30. Mojiri A (2011) Effects of municipal waste water on physical and chemical properties of saline soil. J Biol Environ Sci 5(14):71-76

31. Mojiri A, Amirossadt Z (2011) Effect of urban waste water on accumulation of heavy metals in soil and corn (Zea mays L.) with sprinkler irrigation method. Asian J Plant Sci 1-5

32. Onweremadu EU (2008) Physico-chemical characterization of a farmland affected by waste water in relation to heavy metals. J Zhejiang Univ Sci A 9(3):366-372

33. Paivoke EA (2003) Mineral elements and phytase activity in Pisum sativum plants grown at different $\mathrm{Zn}$ supply levels in green house. Environ Exp Bot 49:285-294

34. Quevauviller P, Rauret R, Rubio G, Lopezsanchez JF, Ure AM, Bacon JR, Muntau H (1997) Certified reference materials for the quality control of EDTA- and acetic acid-extractable contents of trace elements in sewage sludge amended soils (CRMs 483 and 484). Fres J Anal Chem 357:611-618

35. Rahmani HR (2007) Use of industrial and municipal effluent water in Esfahan province. Iran Sci Res Essay 2(3):84-88

36. Rai S, Chopra AK, Pathak C, Sharma DK, Sharma R, Gupta PM (2011) Comparative study of some physicochemical parameters of soil irrigated with sewage water and canal water of Dehradun city. India Arc App Sci Res 3(2):318-325

37. Ramirez-Fuentes E, Lucho CC, Escamilla SE, Dendooven L (2002) Characteristics, and carbon and nitrogen dynamics in soil irrigated with waste water for different lengths of time. Bioresour Technol 85:179-187

38. Rattan RK, Dutta SP, Chhonkar PK, Suribabu K, Singh AK (2005) Long-term impact of irrigation with sewage effluents on heavy metal content in soil crops and ground water-a case study. Agric Ecosyst Environ 109:310-322

39. Rusan MJM, Hinnawi S, Rousan L (2007) Long-term effect of waste water irrigation of forage crops on soil and plant quality parameters. Desalination 215:143-152

40. Saravanamoorthy MD, Kumari BDR (2005) Effect of cotton yarn dye effluent on physiological and biochemical contents of peanut (Arachis hypogaea L. cv. TMV-10) and green gram (Phaseolus radiatus L. cv. K1). Biochem Cell Arch 5(1): 113-117 
41. Sharma RK, Agrawal M, Marshall FM (2007) Heavy metals contamination of soil and vegetables in suburban areas of Varanasi, India. Ecotoxicol Environ Saf 66:258-266

42. Singh KP, Mohan D, Sinha S, Dalwani R (2004) Impact assessment of treated/untreated waste water toxicants discharge by sewage treatment plant on health agricultural and environmental quality in waste water disposal area. Chemosphere 55:227-255

43. Singh A, Sharma RK, Agrawal M, Marshall FM (2009) Effects of waste water irrigation on physicochemical properties of soil and availability of heavy metals in soil and vegetables. Commun Soil Sci Plant Anal 40:3469-3490

44. Singh A, Sharma RK, Agrawal M, Marshall FM (2010) Health risk assessment of heavy metals via dietary intake of foodstuffs from the waste water irrigated site of a dry tropical area of India. Food Chem Toxicol 48:611-619

45. Sinha S, Gupta AK, Bhatt K, Pandey K, Rai UN, Singh KP (2006) Distribution of metals in the edible plants grown at Jajmau, Kanpur (India) receiving treated tannery waste water, relation with physico-chemical properties of the soil. Environ Monit Assess 115:1-22

46. Tabatabai MA (1982) Methods of soil analysis. In: Page AL, Miller RH, Keeney DR (eds) Part 2: chemical and microbiological properties, 2nd edn. Agronomy, No. 9, ASA, SSSSA Publi. Madison

47. Vance ED, Brookes PC, Jenkinson DS (1987) An extraction method for measuring soil microbial biomass C. Soil Biol Biochem 19:703-707

48. Vazquezmontiel O, Horan NJ, Mara DD (1996) Management of domestic waste water for reuse in irrigation. Water Sci Technol 33(10-11):355-362

49. Verloo M, Eeckhout M (1990) Metal species transformation in soil: an analytical approach. Int J Environ Anal Chem 39:179-186

50. Yadav RK, Goval B, Sharma RK, Dubey SK, Minhas PS (2002) Post irrigation impact of domestic sewage effluents on composition of soils, crops and ground water-a case study. Environ Int $28: 481-486$ 